\title{
SPOTLIGHT
}

\section{Politics and policies: making change happen}

The geopolitical consequences of climate change are real and imminent, says Hinrich Thölken, and an issue for Europe and Europe's foreign services

\author{
Hinrich Thölken head of division: climate and environmental foreign policy
}

German Foreign Ministry, Werderscher Markt 1, 10117 Berlin, Germany

The onset of climate change means that for the first time in modern human history our physical environment is no longer stable. Yet our rules for peaceful coexistence on an increasingly crowded planet have always assumed a stable environment. Geographical borders, watercourses, and coastlines have been understood as constants, but this seems no longer true.

Climate change requires us then to rethink some basic principles of geopolitical importance. We may need to revisit the laws of the sea and laws concerning natural resources. We may have to rethink the concept of national sovereignty. Adapting our geopolitics to a changing environment is a task for foreign policy.

In human history conflicts arise over access to resources and territories. Climate change will affect both. We will increasingly be short of such vital resources as fresh water, food, and clean energy. Rising sea levels and increased frequency of extreme weather events will render whole stretches of territory uninhabitable or no longer economically viable. Low lying coastal areas and islands may simply disappear.

We have no rules to clarify what will happen to the economic zones of islands and territories that have sunk into the sea. Arguments over single rocks and sand banks have erupted in the past, so it's likely that the disappearance of such territories will lead to tensions and conflicts. Borders that follow coastlines, riverbeds, and river deltas will start shifting. Loss of territory may trigger migration and exacerbate tensions. We are currently unprepared for such problems; the situation requires preventive and far sighted foreign policy to come up with solutions.

Here are three suggestions.

Firstly, high level foreign policy forums need to engage with the problem. When the United Kingdom took the topic of climate change to the United Nations Security Council in 2007 it met strong opposition. There was a debate, but no written statement could be agreed on. Germany had been explicit in its campaign for a seat on the Security Council that climate change would be one of the major topics for its time there, and reintroduced the topic in July 2011. During the July debate, the
Security Council accepted a presidential statement that climate change posed a threat to peace and security. The UN secretary general was asked to include the subject of climate change in his report to the Security Council.

En route to this result it was felt strongly that not all UN members, and not all Security Council members, agreed on the fundamental importance of climate change as a risk to peace and stability. Negotiations for the presidential statement were tough. Some argued that it was wrong to introduce a subject that wasn't part of the Security Council's original brief; others argued that its introduction might wrest control of the topic from the UN Framework Convention on Climate Change. We found it interesting that as a collective the Group of 77 nations (G-77) opposed discussion of climate change within the Security Council, but that many individual G-77 members strongly supported the initiative and even congratulated us after the successful outcome of the debate.

Is also necessary to rethink how we handle climate change within Europe and the European Union. At the European level so far, climate change has been predominantly the domain of environment ministers, with foreign ministers only occasionally involved. However, in July 2011 Germany and the UK introduced the topic in a joint initiative to the Foreign Affairs Council, which brought to the attention of ministers the diplomatic challenges of climate change.

Secondly, we must work harder to make politicians worldwide understand what needs to happen. Successful climate policy means that we have to adopt low carbon energy production and transport. We need to find low carbon ways to produce food, minimising the generation of greenhouse gases. Known resources of fossil fuels can be exploited only to a very limited extent, as they would produce a carbon load that would by far exceed acceptable limits. Peak oil is no longer a relevant issue; rather peak $\mathrm{CO}_{2}$ emissions is what we should be looking at. $\Downarrow$

If all known resources of fossil fuels were exploited and burned it would lead to 100 times more $\mathrm{CO}_{2}$ emissions than we can allow ourselves, if we want to stay within the two degree limit 
on global temperature increase over pre-industrial levels. That means more than $90 \%$ of all known oil, gas, and coal reserves have to stay in the ground. Imagine what this means to economies dependent on producing and selling fossil fuels. To believe that such a shift in geopolitical paradigms could take place without major disturbances of international relations is naïve.

So we are trying to reach a new balance of interests. We need to find a balance between the interests of industrialised countries and developing countries, between exporters and importers of fossil fuels, between technologically advanced and less advanced economies, and between vulnerable and more robust regions. Climate change is a global factor with massive economic, legal, energy, and financial implications, and it will be one of the key determining factors of international relations.

The view that climate negotiations are nothing less than global economic conferences aiming at redistributing resources is gaining more and more credibility. Climate change may easily become the 21st century's biggest foreign policy challenge, comparable with the challenge of the cold war in the second half of the 20th century. Climate change could endanger human rights. It could endanger human lives by cutting off millions from food and drinking water. In the end, climate change could do as much harm as tanks and guns.

The third suggestion is for dialogue with the public. Politicians and government representatives need to tell people that climate change is a topic not only for scientists and experts but for everybody. Politicians themselves need to increase their level of scientific literacy. Climate change is a difficult subject, but people have the right and the capacity to know what is at stake and what their choices are. Our experience in Germany is that consumers are willing to make a choice for the environment and for the protection of the climate. Many people have, for example, chosen electricity that is produced by renewable energy sources, energy-saving light bulbs, food that is produced in an ecologically sound way, and so on. Consumers seem willing to pay more for products with a positive ecological label. A key to the necessary transformation of our economy is giving people a choice and at the same time providing them with ample information.

There are enormous challenges ahead, but they are not insurmountable. In Europe we are uniquely placed to play a pivotal role in international climate diplomacy, and the decisions we make will be influential in determining how others act.

National foreign services have demonstrated an ability to show leadership and to engage with and broker agreements on some of the most challenging issues. They can and should be a major force in addressing the threats to security and growth posed by climate change.

HT has almost 20 years of experience in international relations. Since taking over his present position in mid-2010 he has sought to increase the role of foreign policy in international climate policy. He is engaged in national, European, and international policy dialogues and strategic policy planning. HT is guarantor.

Competing interests: The author has completed the ICMJE uniform disclosure form at www.icmje.org/coi_disclosure.pdf (available on request from the corresponding author) and declares: no support from any organisation for the submitted work; no financial relationships with any organisations that might have an interest in the submitted work in the previous three years; and no other relationships or activities that could appear to have influenced the submitted work.

Provenance and peer review: Commissioned; not externally peer reviewed.

Accepted: 21 February 2012

Cite this as: BMJ 2012;344:e1356

(c) BMJ Publishing Group Ltd 2012 


\section{Figure}

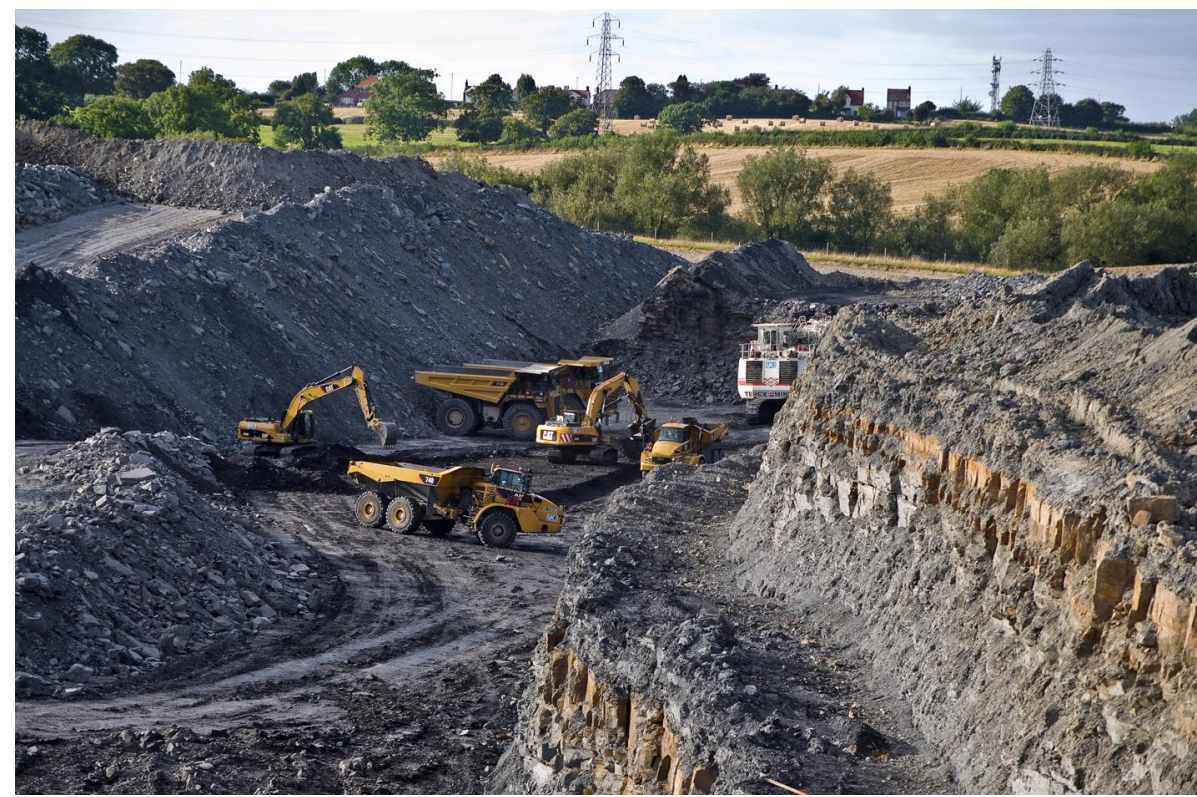

[IImage: CHRIS NAPTON/SCIENCE PHOTO LIBRARY] 